\title{
2. The predominant interpretation of the right to health
}

\section{INTRODUCTION}

A description of the right to health under international human rights law would not be original work. Brigit Toebes, in her Right to Health as a Human Right in International Law, ${ }^{1}$ carried out such a task in a work that two decades after its publication still remains an obligatory reference in literature on the right to health. Instead, this chapter intends to provide an account of the way in which this human right has been authoritatively interpreted. I have labelled the set of views comprising that understanding the predominant interpretation of the right to health.

The Universal Declaration of Human Rights and the International Covenant on Economic, Social and Cultural Rights are the instruments that I consider the lex lata dimension of the right to health. My analysis extends to the text of the right to health under these two instruments, including some references to the travaux préparatoires. According to Matthew Craven, the utility or value of the travaux préparatoires should be read in the light of Article 32 of the Vienna Convention on the Law of Treaties. ${ }^{2}$ Namely, they have the purpose of 'confirm[ing] the meaning resulting from the application of Article 31, or to determine the meaning when the interpretation according to Article 31: a) leaves the meaning ambiguous or obscure; or b) leads to a result which is manifestly absurd or unreasonable'. ${ }^{3}$ Although various provisions on the right to health can be encountered in other important human rights treaties such as the Convention on the Rights of the Child ${ }^{4}$ and the Convention on the Elimination

\footnotetext{
1 Brigit Toebes, The Right to Health as a Human Right in International Law (Intersentia 1999).

2 Matthew Craven, The International Covenant on Economic, Social and Cultural Rights: A Perspective on its Development (Clarendon Press 1995) 3.

3 Vienna Convention on the Law of Treaties (adopted 23 May 1969) 1155 UNTS 331 , art 32.

4 Convention on the Rights of the Child (adopted 20 November 1989) 1577 UNTS 3 , art 24 .
} 
of All Forms of Discrimination Against Women, ${ }^{5}$ I have excluded these since they do not add any new elements necessary for the sake of the arguments presented in this work.

After this analysis, I proceed to the way in which these constitutive norms have been interpreted by certain bodies. In the first place, the work of the United Nations Committee on Economic, Social and Cultural Rights (hereafter 'the Committee'). The bulk of its work has been carried out through General Comments that interpret the International Covenant on Economic, Social and Cultural Rights (hereafter 'the ICESCR' or 'the Covenant') - in particular Articles 2(1) and 12 - but also this body's Concluding Observations in processes of international periodic review. I also include the opinions expressed by the Special Rapporteur of the Right to Health and instruments issued by the United Nations Office of the High Commissioner of Human Rights. Finally, I also include documents from the International Commission of Jurists. As I explain further on, the work of this organization has been crucial to the development of these interpretations. Although the Committee is the body that officially interprets the Covenant, I regard its interpretation lex ferenda. In contrast to the treaty itself, these interpretations have varied with time and State Parties are not obliged to follow the Committee's view. Hence, discussing the coherency of this interpretation in the light of the promises of the integration and indivisibility of all human rights is an exercise to which legal scholars should contribute. In this regard, my input seeks to contribute to the effective realization of the Covenant.

\section{THE UNIVERSAL DECLARATION OF HUMAN RIGHTS}

The Universal Declaration of Human Rights (hereafter 'the Universal Declaration'), the International Covenant on Civil and Political Rights and the ICESCR comprise the Bill of Human Rights. The Universal Declaration constitutes the apex of the international human rights order. Adopted in Paris on 10 December 1948, the Universal Declaration influences the full body of human rights law. While my focus is on the right to health, looking at the context in which the Universal Declaration and the Covenant have emerged helps to introduce this right and the dilemmas inherent to its interpretation.

In spite of the different ideologies of the drafters of the Universal Declaration, a consensus is discernible within the Commission on Human Rights (hereafter 'the Commission') with regard to the intention to include economic, social

5 Convention on the Elimination of All Forms of Discrimination Against Women (adopted 18 December 1979) 1249 UNTS 13, arts 11(1)(f), 11(2)(d), 12(2). 
and cultural rights in its text. ${ }^{6}$ The US, the UK and Australia were the States that most strongly opposed the idea of including such rights in the text of the Universal Declaration. ${ }^{7}$ That the US accepted the inclusion of economic, social and cultural rights can largely be contributed to the conciliatory role played by Eleanor Roosevelt. She defended the legacy of her husband, who had in turn advanced the notion of freedom from want. ${ }^{8}$

Several shifts in the position of the members of the Commission exemplify the ideological adjustments that every State had to make for the Universal Declaration to be adopted. The case of the Soviet Union exemplifies this. From a doctrinal perspective, Marxism is in tension with the language of rights. Marxism has understood rights as bourgeoisie rights: entitlements that can at best be exercised by the capitalist class, and at worst can become a further instrument of oppression against the working classes. ${ }^{9}$ The Soviets would have wished the idea of the 'rights of the State' to prevail, while at the same time denying individual rights. ${ }^{10}$

The inclusion of economic, social and cultural rights is not only the result of principled ideas, but it should also be understood as the result of pragmatic calculation. ${ }^{11}$ Besides the abovementioned ideological adjustment, there was a widely shared view that failing to overcome the destruction and misery of the war would provide fertile soil for the surfacing of doctrines contrary to Western liberal democracy, a perspective put forward by older organizations such as the International Labour Organization. ${ }^{12}$ The delegates, citing the preamble of the Charter of the United Nations ${ }^{13}$ and backed by the ideological legacy of President Roosevelt, made direct mention of the existing relationship

6 Only the South African Union expressed that the UN Charter should not include these rights. According to Samnøy, the only impact of this intervention was that of strengthening the opinion of the delegates to include these rights as South Africa was already very isolated, see Åshild Samnøy, Human Rights as International Consensus: The Making of the Universal Declaration of Human Rights 1945-1948 (Chr. Michelsen Institute 1993) 83.

7 Mary Ann Glendon, A World Made New: Eleanor Roosevelt and the Universal Declaration of Human Rights (Random House 2001) 116; ibid 21-22.

8 Samnøy (n 6) 42-43.

9 Samnøy (n 6) 43-44.

10 M Glen Johnson and Janusz Symonides, The Universal Declaration of Human Rights. A History of its Creation and Implementation, 1948-1998(UNESCO Publishing 1998) 57.

11 Samnøy (n 6) 20-21.

12 Daniel Roger Maul, 'The International Labour Organization and the Globalisation of Human Rights, 1944-1970' in Stefan-Ludwig Hoffmann (ed), Human Rights in the Twentieth Century (CUP 2011) 304.

13 Which begins stating that 'We, the peoples of the United Nations, determined to save succeeding generations from the scourge of war, which twice in our lifetime has 
between the Universal Declaration, freedom from want ${ }^{14}$ and the objective of impeding the scourge of war. ${ }^{15}$

While the interest in developing a declaration was linked to the purpose of building a minimum global agreement in the field of human rights after World War II, the Universal Declaration was largely regarded as not legally binding by the superpowers. ${ }^{16}$ The Secretary of the Commission, John Humphrey, considered that the attitude of the US and other States, which made constant references to the non-binding value of the Universal Declaration, limited its importance and did not contribute to the cause of human rights. ${ }^{17}$ Countries such as Chile and Lebanon, however, attached more than merely moral value to it. ${ }^{18}$ On a similar vein, René Cassin, the French representative, emphasized the danger of considering the Universal Declaration as lacking all legal value and only as an orientation. In his view, the Universal Declaration was supposed to be a supplement to the Charter of the United Nations, providing clarification. ${ }^{19}$ Using the same argument, Chile's representative, Hernán Santa Cruz, suggested that insofar human rights entailed a constitutive part of the principles of the UN, any violation of the Universal Declaration would involve a violation of the Charter. ${ }^{20}$ As the Universal Declaration has gradually become part of international customary law, international law has acknowledged its importance. ${ }^{21}$ Yet, the opinion that prevailed was that of the US, in the sense that the legally binding document would emerge in the form of the future Covenants. ${ }^{22}$

Independent of the question of its legal value, the Universal Declaration has had an important effect. Its norms provided an impulse to emancipatory polit-

brought untold sorrow to mankind', Universal Declaration of Human Rights (adopted 10 December 1948) UNGA Res 217 A (III).

14 The second paragraph of the Preamble of the Declaration states that 'Whereas disregard and contempt for human rights have resulted in barbarous acts which have outraged the conscience of mankind, and the advent of a world in which human beings shall enjoy freedom of speech and belief and freedom from fear and want has been proclaimed as the highest aspiration of the common people'. ibid.

15 Johnson and Symonides (n 10) 55; Glendon (n 7) 238.

16 Hersch Lauterpacht, 'The Universal Declaration of Human Rights' in Joseph Weiler and Alan Nissel (eds), International Law. Critical Concepts in Law, vol 4 (Routledge 2011) 493-521.

17 Johnson and Symonides (n 10) 64-65.

18 Samnøy (n 6) 73; Lauterpacht (n 16).

19 Johnson and Symonides (n 10) 65.

20 ibid 64-65.

21 Toebes (n 1) 40.

22 Johnson and Symonides (n 10) 62. 
ical processes such as the decolonization of Africa, ${ }^{23}$ the creation of regional human rights systems in Europe, the Americas and Africa, and permeated the provisions of several constitutions.

Norms concerning economic, social and cultural rights are included in Articles 22 to 27 of the Universal Declaration. They include the right to social security, the right to work, the right to rest and leisure, the right to an adequate standard of living (which includes adequate medical care), the right to education, the right to participate in the cultural life of the community and the right to an equitable social and international order. The inclusion of economic, social and cultural rights illustrates how the Universal Declaration was not born in an ideological vacuum, but in a context marked by strong social concerns. The delegates developed their work with the legacy of the social policies implemented in the nineteenth and twentieth centuries, but also with the expectation of expanding the welfare state. ${ }^{24}$ Drawing on the experience of social policies from Western Europe, the Scandinavian countries, the US' New Deal legislation, the Soviet bloc and some experiences of Latin American countries, the majority of the delegates of the Commission accepted the inclusion of norms of economic and social content. ${ }^{25}$

Conflicts arose in relation to the legal nature and scope that those different norms were supposed to have, an issue that remains controversial today and which is exemplified in the right to health. Not only because the language that was used to address the right to health varies considerably from the Universal Declaration to the Covenant, but also because these different notions coincide with different conceptions about the role of the State, its relationship to the economy, the division line between the public and the private realm, and the overall definitions of the nature and scope of human rights. ${ }^{26}$

23 ibid 67; Jochen von Bernstorff, 'The Changing Fortunes of the Universal Declaration of Human Rights: Genesis and Symbolic Dimensions of the Turn to Rights in International Law' (2008) 19(5) The European Journal of International Law 903, 912.

24 Bård-Anders Andreassen, 'Article 22' in Gudmundur Alfredsson and Asbjørn Eide (eds), The Universal Declaration of Human Rights: A Common Standard of Achievement (Martinus Nijhoff Publishers 1999).

${ }_{25}$ The Chilean delegate Hernán Santa Cruz played an important role in this respect, see Johannes Morsink, The Universal Declaration of Human Rights: Origins, Drafting, and Intent (University of Pennsylvania Press 1999) 89-90, 131.

26 Andreassen (n 24) 477. 


\section{THE INTERNATIONAL COVENANT ON ECONOMIC, SOCIAL AND CULTURAL RIGHTS}

I shall discuss two issues here. First, I shall pose a question which I will attempt to answer further on concerning the individual legal scope of the rights enshrined in the Covenant. Secondly, I shall assess a few issues that emerged in the context of the Covenant's travaux préparatoires regarding the material scope of the obligations established in Article 12.

Are the rights enshrined in the Covenant exclusively legal rights? A stark contrast can be found in terms of the different scope of the provisions of the International Covenant on Civil and Political Rights by comparison to the ICESCR. While the International Covenant on Civil and Political Rights establishes that: 'Each State Party to the present Covenant undertakes to respect and to ensure to all individuals (emphasis added) within its territory and subject to its jurisdiction the rights recognized in the present Covenant ..., ${ }^{27}$ the ICESCR established that: 'Each State Party to the present Covenant undertakes to take steps ...'. This is a significant omission in the Economic, Social and Cultural Rights Covenant compared to the Civil and Political Rights Covenant. I am not referring to the largely theorized discussion between the language of 'respecting and ensuring' compared to the language of 'taking steps' ${ }^{28}$ Rather, I am asking: who are the beneficiaries of the Economic, Social and Cultural Rights Covenant? The reference to 'all individuals' of the Civil and Political Rights Covenant seems to be linked to the importance of excluding non-individuals such as corporations. ${ }^{29}$ However, such a strong emphasis is still remarkable when compared to the total absence of any such mention by the Economic, Social and Cultural Rights Covenant. By the same token, the most important legal comments written about the ICESCR - by Craven ${ }^{30}$ and Saul and others ${ }^{31}$

27 International Covenant on Civil and Political Rights (adopted 16 December 1966) 999 UNTS 171, art 2(1).

28 Asbjørn Eide and Allan Rosas, 'Economic, Social and Cultural Rights: A Universal Challenge' in Asbjørn Eide, Catarina Krause and Allan Rosas (eds), Economic, Social and Cultural Rights: A Textbook (2nd edn, Martinus Nijhoff Publishers 2001) 23.

29 Thomas Buergenthal, 'To Respect and to Ensure: State Obligations and Permissible Derogations' in Louis Henkin (ed), The International Bill of Rights. The Covenant on Civil and Political Rights (Columbia University Press 1981) 72, 73; also Marc J Bossuyt, Guide to the 'Travaux Préparatoires' of the International Covenant on Civil and Political Rights (Martinus Nijhoff Publishers 1987) 53.

30 Craven (n 2).

31 Ben Saul, David Kinley and Jacqueline Mowbray, The International Covenant on Economic, Social and Cultural Rights: Commentary, Cases, and Materials (OUP 2014). 
- make no reference to this issue. The debate has mostly been centred in what is now an old discussion of whether economic, social and cultural rights can or cannot be considered justiciable rights. ${ }^{32}$ What I think these perspectives have failed to address is that this omission might reflect to the fact that the nature of social rights does not sit comfortably in an individualized scheme.

A second topic of interest concerns the travaux préparatoires of Article 12, which took place during the seventh and eighth session of the Commission. Discussions also took place in the Third Committee of the United Nations General Assembly. ${ }^{33}$

The right to an adequate standard of living in the Universal Declaration was made the object of a specific provision in Article 11 of the Covenant. In turn, the notion of adequate medical care from the Universal Declaration was transformed in the more comprehensive right to the highest attainable standard of physical and mental health of Article 12 of the Covenant. For this, the drafters of the Covenant relied less on the Universal Declaration and more on the older language taken from the Constitution of the World Health Organization (WHO) ${ }^{34}$ While the Universal Declaration was adopted on 10 December 1948, the Constitution of the WHO was adopted at the First World Health Assembly, held in New York on 22 July 1946. The Constitution of the WHO stated in its Preamble that 'the enjoyment of the highest attainable standard of health is one of the fundamental rights of every human being without distinction of race, religion, political belief, economic or social condition'. Further, its Article 1 stated that 'the objective of the World Health Organization (hereinafter called the Organization) shall be the attainment by all peoples of the highest possible level of health'. The decision to follow the definition of the right to health as established in the Constitution of the WHO was adopted in opposition to the views of the representative from China, who proposed that the right to health should be limited to the obligations of the government with respect to this agency. ${ }^{35}$ The opinion that prevailed was that of the representative of the Soviet Union, who proposed that the text should contain concrete obligations for the governments. ${ }^{36}$ This perspective was supported by the representative of Chile, who highlighted the responsibility of the State in the adoption of pre-

32 Eide (n 28) 10; UNCESCR, 'General Comment 9: The domestic application of the Covenant', UN Doc E/C.12/1998/24, 3 December 1998, para 10; Martin Scheinin, 'Justiciability and the Indivisibility of Human Rights' in John Squires, Malcolm Langford, Bret Thiele (eds), The Road to a Remedy: Current Issues in the Litigation of Economic, Social and Cultural Rights (Australian Human Rights Centre 2005) 17.

33 Toebes (n 1) 41.

34 ibid 43.

35 ibid.

36 ibid. 
ventive measures against diseases through public healthcare services. ${ }^{37}$ These opinions were supported by the majority, and are reflected in the proposal of Egypt, further modified by the US and Chile. ${ }^{38}$

Another important point was linked to the definition of health. Although the Commission did not incorporate this concept in the text of the Covenant, this was because the WHO's definition of health was largely considered embedded in the Covenant. ${ }^{39}$ Its definition made reference not only to the absence of illness, but it also extended to a complete state of physical, mental and social health. ${ }^{40}$ Although the proposal to include that definition was expressly rejected, ${ }^{41}$ the obligations that are mentioned in the second part of the Article reflect that this broader concept of health was indeed adopted. ${ }^{42}$

Another important issue concerned the content of the obligations. The opinion that prevailed was that of the Soviet Union's representative, which included 'medical service' and 'medical attention' ${ }^{43}$ This was because despite the importance of a correct diagnosis, access to medicines, hospitalization and other similar elements were also considered necessary, especially given that in many countries both drugs and healthcare treatments were very expensive. ${ }^{44}$

Similarly, the obligations enumerated under paragraph 2 of Article 12 should be understood only as examples that at the time of the draft were considered urgent and not a type of exhaustive enumeration..$^{45}$ Despite that, Roscam Abbing opines that Article 12 only constitutes a reference to the conditions deemed essential for the protection and promotion of individual health.

\footnotetext{
37 HDC Roscam Abbing, International Organisations in Europe and the Right to Health Care (Kluwer 1979) 72.

38 ibid.

39 Toebes (n 1) 43.

40 Such a definition indicates 'Health entails a complete state of physical, mental and social wellbeing, and not just the complete absence of diseases', WHO, Constitution of WHO as adopted by the International Health Conference, New York, 19 June-22 July 1946, signed on 22 July 1946 by the representatives of 61 States (Official Records of WHO, no 2, p 100) and entered into force on 7 April 1948.

41 Toebes (n 1) 48.

42 ibid 51-52.

43 ibid 43-44.

44 ibid 44

$45 \quad$ Roscam Abbing (n 37) 77.
} 
The final provision of Article 12 reads as follows:

1) The States Parties to the present Covenant recognize the right of everyone to the enjoyment of the highest attainable standard of physical and mental health.

2) The steps to be taken by the States Parties to the present Covenant to achieve the full realization of this right shall include those necessary for:

a) The provision for the reduction of the stillbirth-rate and of infant mortality and for the healthy development of the child;

b) The improvement of all aspects of environmental and industrial hygiene;

c) The prevention, treatment and control of epidemic, endemic, occupational and other diseases;

d) The creation of conditions which would assure to all medical service and medical attention in the event of sickness.

It is clear that the path towards this provision was not simple, but the result of delicate balances and complex political compromises. The difficulty in clearly identifying the duty bearer of this human right should be understood against the dissimilar ideological backgrounds of the drafters of the provision.

\section{THE PATH TOWARDS OFFICIAL STATUS}

\subsection{Introduction}

By 'predominant interpretation of the right to health', I refer to a set of views put forward by a group of authoritative bodies within the United Nations. These bodies include the Committee, which has deployed its interpretation through General Comments and Concluding Observations, the Special Rapporteur of the Right to Health, which has put forward its perspective through Reports, and the United Nations Office of the High Commissioner of Human Rights, which has contributed through principles and guidelines, including the important Vienna Declaration and Plan of Action, issued after the Human Rights World Conference held in Vienna in 1993. ${ }^{46}$ These views concern the understanding of these bodies of economic, social and cultural rights in general and the right to health in particular. This analysis would be incomplete if the work of the International Commission of Jurists was not mentioned. The depth of its contributions is remarkable; not only because of the coherence of its focus, but also because of the impact it has had on the work of the United Nations.

While the Covenant came into force in 1976, one decade later the International Commission of Jurists issued the Limburg Principles on the Implementation of the International Covenant on Economic, Social and

46 OHCHR, 'Vienna Declaration and Programme of Action', UN Doc A/ CONF.157/23, 12 July 1993, para 5. 
Cultural Rights. ${ }^{47}$ These Principles are a set of guidelines that resulted from a discussion held at the request of the International Commission of Jurists, the Urban Morgan Institute for Human Rights and the University of Cincinnati. The goal of the meeting was to elaborate on the legal nature and scope of the obligations of the State Parties regarding the ICESCR, the nature of the reports of State Parties, the role of the Committee and the theme of international cooperation. In 1997, exactly one decade after this crucial contribution, the International Commission of Jurists issued the Maastricht Guidelines on Violations of Economic, Social and Cultural Rights. ${ }^{48}$ These Guidelines further elaborated on the topic of the nature and scope of the violations of economic, social and cultural rights, as well as appropriate responses and remedies. In 1995, shortly before the Maastricht Guidelines, the Commission issued the Bangalore Declaration and Plan of Action ${ }^{49}$ an instrument that emphasized the role of lawyers, contributing to settling a judicial focus on the understanding of economic, social and cultural rights. As recently as 2011, a group of renowned international scholars in the field of economic, social and cultural rights participated in issuing the Maastricht Principles on the Extraterritorial Obligations of States in the Area of Economic, Social and Cultural Rights. ${ }^{50}$ This set of guidelines, released at the request of the International Commission of Jurists, complemented the United Nations Office of the High Commissioner of Human Rights' Principles of Business and Human Rights. ${ }^{51}$ They reflected the complex challenges faced by human rights law in the context of globalization.

Describing social rights, such as the right to health, only as legal obligations derived from a multilateral treaty would fall short of an adequate clarification. The nature and scope of social rights involves a political and philosophical debate about the justification of human and people's rights. As these different

47 UNCHR, 'Note Verbale Dated 5 December 1986 from the Permanent Mission of the Netherlands to the United Nations Office at Geneva Addressed to the Centre for Human Rights (“Limburg Principles")' UN Doc E/CN.4/1987/17, 8 January 1987, para 5 (Limburg Principles).

48 The Maastricht Guidelines on Violations of Economic, Social and Cultural Rights, 26 January $1997<$ https://www.refworld.org/docid/48abd5730.html> accessed 3 February 2021 (Maastricht Guidelines).

49 International Commission of Jurists (ICJ) 'Bangalore Declaration and Plan of Action', 1995 (Bangalore Declaration).

50 Maastricht Principles on Extraterritorial Obligations of States in the Area of Economic, Social and Cultural Rights, adopted 28 September 2011, available at multiple places online including <https://www.etoconsortium.org/nc/en/main-navigation/ library/maastricht-principles/?tx_drblob_pi1\%5BdownloadUid $\% 5 \mathrm{D}=23>$ accessed 3 February 2021 (Maastricht Principles).

51 OHCHR, 'Guiding Principles on Business and Human Rights', HR/PUB/11/04, June 2011. 
views impact the way the State and its role in the economy is understood, further implications for the scope of social rights also emerge. For this reason, although the purpose of these various instruments is to answer a very concrete legal question - what obligations does the Covenant impose upon State Parties? - such a question is intrinsically connected to the different political and philosophical traditions under which these rights are defined. While my focus remains on the legal perspective, I attempt to look more broadly at the nature, scope and effects of the right to health beyond a purely judicial conception. Hence, while the coming Sections of this chapter describe what this interpretation amounts to, chapters four, five and six will deal with the dilemmas that arise from this understanding.

In the next Sections of this chapter, my method will be to intertwine the various instruments. I provide a step-by-step description, so that the various instruments can speak for themselves. For this reason, I have literally inserted texts from the relevant instruments, making only a few editorial remarks. The chapter concludes with a list of challenges I believe are problematic from this perspective.

\subsection{Elements Conforming to the Predominant Interpretation of the Right to Health}

\subsubsection{Legal nature of economic, social and cultural rights}

All human rights constitute an indivisible, interdependent and interrelated whole. One of the basic understandings of what is known as human rights integration is that economic, social and cultural rights are as important as civil and political rights for human dignity. ${ }^{52}$

The path chosen to provide uniformity in the importance between classical rights on the one hand and economic, social and cultural rights on the other, was that of legal rights, namely, their ability to become legally justiciable. An important ICJ declaration admitted the tendency to legalize issues that were most appropriately decided in a context, and according to considerations larger than those typically found in courts of law. ${ }^{53}$ However, the same declaration recognized the important function of both lawyers and judges in the development of these rights. In India, for example, lawyers and judges have made possible the judicial enforcement of 'economic, social and cultural rights in the context of the right to life, fair trial, equality before the law, equal protection

52 Limburg Principles (n 47) paras 1, 3; ICJ, Bangalore (n 49) para 5; Maastricht Guidelines (n 48) paras 3, 4 .

53 ICJ, Bangalore (n 49) para 11. 
of the law and other civil and political rights'. ${ }^{54}$ Jurists, maintained this declaration, 'should play a greater part in the realization of such rights [economic, social and cultural]'. ${ }^{55}$ Access to an effective remedy should be extended to protect, via litigation, economic, social and cultural rights. ${ }^{56}$

The natural development of this path at the UN level consisted of making the Covenant justiciable. That was indeed the function taken by the Covenant's Optional Protocol, which entered into force in $2013,{ }^{57}$ allowing for an individual complaints mechanism. ${ }^{58}$

Moreover, in line with development theories popular in the 1990s, the justiciability of social rights was seen as being naturally compatible with development approaches based on the idea of capabilities. From this perspective, rights are conceived 'as both constitutive of and instrumental to the overall process of development; that is, rights and freedoms are not only necessary tools in achieving the goals of development, but the realization of rights should constitute an end-goal of development itself' ${ }^{59}$ In a similar vein, compatibility was also envisioned with so-called 'human rights-based approaches'. According to a report from a human rights rapporteur on the right to health, 'a human rights-based approach requires special attention be given to disadvantaged individuals and communities; it requires the active and informed participation of individuals and communities in policy decisions that affect them; and it requires effective, transparent and accessible monitoring and accountability mechanisms'. ${ }^{60}$ The adoption of a right to health framework, in respect of

$54 \quad$ ICJ, Bangalore (n 49) para 12.

55 ibid; Maastricht Guidelines (n 48) para 28; UNCESCR, 'General Comment 14 The Right to the Highest Attainable Standard of Health', UN Doc E/C.12/2004/4, 11 May 2000, para 61; UNCESCR, 'Concluding Observations of the Committee on Economic, Social and Cultural Rights, Benin', UN Doc E/C.12/1/Add.78, 5 June 2002, para 30 .

56 UNCESCR, 'Concluding Observations on the Combined Second and Third Periodic Reports of Tajikistan', UN Doc E/C.12/TJK/CO/2-3, 25 March 2015, para 7; UNCESCR, 'Concluding Observations on the Sixth Periodic Report of Canada', UN Doc E/C.12/CAN/CO/6, 23 March 2016, paras 5, 6; OHCHR, 'Economic, Social and Cultural Rights: Handbook for National Human Rights Institutions' (Professional Training Series 12, United Nations, 2005) 25-27.

57 Optional Protocol to the International Covenant on Economic, Social and Cultural Rights, UNGA A/RES/63/117, 10 December 2008.

58 ICJ, Bangalore (n 49) paras 4, 7; Maastricht Guidelines (n 48) paras 3, 31.

59 UNHRCL, 'Report of the Special Rapporteur on the Right of Everyone to the Enjoyment of the Highest Attainable Standard of Physical and Mental Health, Anand Grover', UN Doc A/HRC/17/25, 12 April 2011, para 11.

60 UNCHR, 'Report of the Special Rapporteur on the Right of Everyone to the Enjoyment of the Highest Attainable Standard of Physical and Mental Health, Paul Hunt', UN Doc E/CN.4/2006/48, 3 March 2006, paras 25, 26; concerning drug addic- 
health, and of human rights-based approaches more generally, is one method by which genuine synchronicity can be achieved in respect of health-related development work and human rights. ${ }^{61}$

Finally, an independent judiciary is considered indispensable for the effective implementation of economic, social and cultural rights. ${ }^{62}$

\subsubsection{Abidance to the tripartite typology of duties}

Reference to the respect, protect and fulfil framework has been recurrent in the context of human rights, particularly regarding economic, social and cultural rights. ${ }^{63}$ The obligation to respect requires States to refrain from interfering with the enjoyment of economic, social and cultural rights. ${ }^{64}$ The obligation to protect requires States to prevent the violation of such rights by third parties. ${ }^{65}$ Finally, the obligation to fulfil requires States to take appropriate legislative,

tion, see UNCESCR, 'Concluding Observations on the Combined Fourth to Sixth Periodic Report of Belarus', UN Doc E/C.12/BLR/CO/4-6, 13 December 2013, para 25; concerning the prevention of maternal morbidity and mortality, see UNCESCR, 'Concluding Observations on the Fourth and Fifth Periodic Report of Angola', UN Doc E/C.12/AGO/CO/4-5, 15 July 2016, para 52 (a); concerning the use of tobacco addiction, see UNCESCR, 'Concluding Observations on the Initial Report of Indonesia', UN Doc E/C.12/IDN/CO/1, 19 June 2014, para 35 (d); concerning persons with disabilities, see UNCESCR, 'Concluding Observations on the Second Periodic Report of Lebanon', UN Doc E/C.12/LBN/CO/2, 24 October 2016, para 22(b).

${ }_{61} \mathrm{UNHRCL}, \mathrm{A} / \mathrm{HRC} / 17 / 25$ (n 59) para 17; it is interesting to note that the approach extends even to the field of international cooperation, see UNCESCR, 'Concluding Observations on the Sixth Periodic Report of the United Kingdom of Great Britain and Northern Ireland', UN Doc E/C.12/GBR/CO/6, 14 July 2016, para 15 and UNCESCR, 'Concluding Observations on the Third Periodic Report of Japan, Adopted by the Committee at its Fiftieth Session (29 April-17 May 2013)', UN Doc E/C.12/JPN/CO/3, 10 June 2013, para 32.

${ }_{62}$ ICJ, Bangalore (n 49) paras 14, 18(4); UNCESCR, 'Concluding Observations of the Committee on Economic, Social and Cultural Rights, Azerbaijan', UN Doc E/C.12/1/Add.20, 22 December 1997, para 15; UNCESCR, 'Concluding Observations of the Committee on Economic, Social and Cultural Rights, Uzbekistan', UN Doc E/C.12/UZB/CO/1, 24 January 2006, para 37; UNCESCR, E/C.12/TJK/CO/2-3 (n 56) para 8 .

${ }_{63}$ Maastricht Guidelines (n 48) para 6; UNCESCR, Comment 14 (n 55) paras 33-37; OHCHR, Business (n 51); UNCESCR, 'Concluding Observations of the Committee on the Second Periodic Report of Greece', UN Doc E/C.12/GRC/CO/2, 27 October 2015, para 8.

64 UNCESCR, 'Concluding Observations of the Committee on Economic, Social and Cultural Rights, The Kingdom of the Netherlands', UN Doc E/C.12/NDL/CO/4-5, 9 December 2010, para 28.

65 UNCESCR, 'Concluding Observations on the Second Periodic Report of China, Including Hong Kong, China, and Macao, China', UN Doc E/C.12/CHN/CO/2, 13 June 2014, para 8. 
administrative, budgetary, judicial and other measures towards the full realization of such rights. ${ }^{66}$

\subsubsection{The law and politics relationship}

Should States adapt their political and economic regimes in order to comply with the obligations imposed by the Covenant? Although the trend of reducing the role of the State and to rely on the market to resolve problems of human welfare is admitted, ${ }^{67}$ the official view seems to be that this obligation can be met in the context of various political settings, including the market economy. ${ }^{68}$ The Covenant would thus be politically neutral.

\subsubsection{Obligation to take steps under Article 2(1) of the Covenant}

From a rationae temporae perspective, the relevant question is when should States comply with the obligations imposed by the Covenant. In this sense, the treatment regarding the prohibition of discrimination is stronger than the other rights as immediate implementation in full is contemplated, ${ }^{69}$ allowing also for judicial review..$^{70}$ As to the rest of the provisions of the Covenant, implementation takes place through progressive realization. ${ }^{71}$ Nonetheless, State Parties are expected to move as expeditiously as possible towards the full realization

66 UNCESCR, E/C.12/GRC/CO/2, 27 (n 63) para 36(a).

67 Maastricht Guidelines ( $\mathrm{n} 48$ ) para 2; UNHRCL, 'Report of the Special Rapporteur on the Right of Everyone to the Enjoyment of the Highest Attainable Standard of Physical and Mental Health, Paul Hunt' (31 January 2008) UN Doc A/HRC/7/11, para 27.

68 Limburg Principles (n 47) para 6; UNCESCR, 'General Comment 3: The Nature of States Parties' Obligations (Art 2, Para. 1, of the Covenant)', UN Doc E/1991/23, 14 December 1990, para 8; ICJ, Bangalore (n 49) para 5; UNCESCR, 'Concluding Observations of the Committee on Economic, Social and Cultural Rights, Poland', UN Doc E/C.12/1/Add.26, 16 June 1998, para 9.

${ }_{69}$ Limburg Principles (n 47) paras 8, 22; UNCESCR, Comment 3 (n 68) para 1; UNCESCR, 'General Comment 20 Non-Discrimination in Economic, Social and Cultural Rights (Art 2, Para 2 of the International Covenant on Economic, Social and Cultural Rights)', UN Doc E/C.12GC/20, 4-22 May 2009, para 7; UNCESCR, 'Concluding Observations of the Committee on Economic, Social and Cultural Rights, Canada', UN Doc E/C.12/CAN/CO/4-5, 22 May 2006, para 50.

70 Limburg Principles (n 47) para 35; UNCESCR, E/C.12/CAN/CO/4-5 (n 69) para 36; UNCESCR, 'Concluding Observations on the Sixth Periodic Report of Sweden' UN Doc E/C.12/SWE/CO/6, 14 July 2016, para 44(b).

${ }_{71}$ Limburg Principles (n 47) paras 16, 21; Maastricht Guidelines (n 48) para 8; UNCESCR, 'Concluding Observations of the Committee on Economic, Social and Cultural Rights, Democratic Republic of Congo' UN Doc E/C.12/COD/CO/4, 16 December 2009, para 16. 
of the rights of the Covenant. ${ }^{72}$ Steps towards that goal must be taken within a reasonably short time after the Covenant's entry into force, and they should be deliberate, concrete and targeted as clearly as possible towards meeting the obligations recognized in the Covenant. ${ }^{73}$ In that regard, any deliberately retrogressive measures would require the most careful consideration and would need to be fully justified by reference to the totality of the rights provided for in the Covenant and in the context of the full use of the maximum available resources. ${ }^{74}$

From a rationae personae perspective, the obligations derived from the Covenant apply to both nationals and non-nationals living under the State's jurisdiction. ${ }^{75}$

From a rationae materiae perspective - namely, the question of what States should do and how they should act in order to comply with this obligation - a number of elements can be noted. First, resource scarcity does not relieve States of certain minimum obligations. At least minimum subsistence rights for all should be provided regardless of economic development. States should guarantee a minimum core obligation to ensure the satisfaction of, at the very least, minimum essential levels of each of the rights ${ }^{76}$ as well as the provision of essential services. ${ }^{77}$ Secondly, as stated earlier, the prohibition of discrimination enjoys a strengthened or privileged status within these human rights. ${ }^{78}$ By the same token, the subjective position of disadvantaged

72 Limburg Principles (n 47) para 21; UNCESCR, Comment 3 (n 68) para 9; UNCESCR, Comment 14 (n 55) para 31.

73 UNCESCR, Comment 3 (n 68) para 2; UNCESCR, E/C.12/CAN/CO/4-5 (n 69) para 44; UNCESCR, 'Concluding Observations on the Sixth Periodic Report of Cyprus’ UN Doc E/C.12/CYP/CO/6, 28 October 2016, para 36.

74 UNCESCR, Comment 3 (n 68) para 9; UNCESCR, Comment 14 (n 55) paras 32, 48; UNHRCL, A/HRC/7/11 (n 67) para 49; UNCESCR, E/C.12/1/Add.78 (n 55) paras 28, 56; UNCESCR, 'Concluding Observations of the Committee on Economic, Social and Cultural Rights, India' UN Doc E/C.12/IND/CO/5, 8 August 2008, para 45.

75 Limburg Principles (n 47) para 42.

76 Limburg Principles (n 47) para 25; UNCESCR, Comment 3 (n 68) para 10; Maastricht Guidelines (n 48) paras 9, 10, 14(g); UNCESCR, 'General Comment 2: International Technical Assistance Measures (Art 22 of the Covenant)', UN Doc E/1990/23, 2 February 1990, para 9; UNCESCR, 'General Comment 8: The Relationship between Economic Sanctions and Respect for Economic, Social and Cultural Rights', UN Doc E/C.12/1997/8, 12 December 1997, para 7; UNCESCR, Comment 14 (n 55) para 47; UNHRCL, A/HRC/17/25 (n 59) para 19; UNCESCR, 'Concluding Observations on the Combined Third and Fourth Periodic Reports of Jamaica, Adopted by the Committee at its Fiftieth Session (29 April - 17 May 2013)', UN Doc E/C.12/JAM/CO/3-4, 10 June 2013, para 7.

77 Limburg Principles (n 47) para 28.

78 ibid para 13; UNCESCR, Comment 14 (n 55) paras 18, 19, 30; UNCESCR, Comment 20 (n 69) para 2; UNHRCL, A/HRC/7/11 (n 67) para 43; OHCHR, 'Guiding 
groups is the focus of a great deal of attention. ${ }^{79}$ Thirdly, popular participation

Principles on Extreme Poverty and Human Rights', UN Doc A/HRC/21/11, 26 September 2012, para 57; furthermore, the Committee addresses the right to health in the light of the various prohibited grounds of the discrimination such as non-citizens (see UNCESCR, 'Concluding Observations on the Fifth Periodic Report of Norway' UN Doc E/C.12/NOR/CO/5, 13 December 2013, para 17), the elderly (see UNCESCR, 'Concluding Observations of the Committee on Economic, Social and Cultural Rights, Iraq' UN Doc E/C.12/1/Add.17, 12 December 1997, para 37), internal migrants, nomadic people, stateless persons, ethnic minorities (see UNCESCR, 'Concluding Observations of the Committee on Economic, Social and Cultural Rights, Uzbekistan' UN Doc E/C.12/UZB/CO/2, 13 June 2014, para 9), the position of women vis-à-vis men (see UNCESCR, 'Concluding Observations on the Fourth Periodic Report of Paraguay' UN Doc E/C.12/PRY/CO/4, 20 March 2015, para 14), accessibility of healthcare of those living in rural areas by comparison to those living in urban areas (see UNCESCR, 'Concluding Observations on the Fourth Periodic Report of France' UN Doc E/C.12/ FRA/CO/4, 13 July 2016, para 44), LGBT persons (see UNCESCR, 'Concluding Observations on the Third Periodic Report of Guatemala' UN Doc E/C.12/GTM/CO/3, 9 December 2014, para 9), intersex persons, persons living with HIV/AIDS, women involved in prostitution, persons with a drug addiction, persons with disabilities (see UNCESCR, 'Concluding Observations on the Combined Second and Third Periodic Reports of Kyrgyzstan' UN Doc E/C.12/KGZ/CO/2-3, 7 July 2015, paras 22 (a), 23), asylum seekers (see UNCESCR, 'Concluding Observations on the Fourth Periodic Report of Austria' UN Doc E/C.12/AUT/CO/4, 13 December 2013, para 21), refugees, internally displaced persons (see UNCESCR, 'Concluding Observations on the Second Periodic Report of Serbia' UN Doc E/C.12/SRB/CO/2, 10 July 2014, para 11 (a)), same sex partners, the mentally ill (see UNCESCR, 'Concluding Observations on the Initial Report of Uganda' UN Doc E/C.12/UGA/CO/1, 8 July 2015, paras 32, 34), non-residents (see UNCESCR, 'Concluding Observations of the Committee on Economic, Social and Cultural Rights' UN Doc E/C.12/1/Add.94, 12 December 2003, para 12), rural-to-urban migrant workers (see UNCESCR, 'Concluding Observations on the Second Periodic Report of China, Including Hong Kong, China, and Macao, China' UN Doc E/C.12/CHN/CO/2, 13 June 2014, para 33) displaced persons (see UNCESCR, 'Concluding Observations on the Initial Report of Montenegro' UN Doc E/C.12/MNE/CO/1, 15 December 2014, para 24(c)), and prisoners (see UNCESCR, 'Concluding Observations on the Second Periodic Report of Lithuania' UN Doc E/C.12/LTU/CO/2, 24 June 2014, para 21).

79 Limburg Principles (n 47) para 14; UNCESCR, Comment 20 (n 69) para 27; UNCESCR, Comment 2 (n 76) para 9; the Committee often addresses the situation of specific groups and minority communities that face discrimination. Examples include the Israeli-Arabs, the Palestinians (see UNCESCR, 'Concluding Observations of the Committee on Economic, Social and Cultural Rights, Israel' UN Doc E/C.12/1/Add.27, 4 December 1998, paras 10, 20), the Roma people (see UNCESCR, E/C.12/GRC/CO/2 (n 63) para 9), persons of Afro ascendency (see UNCESCR, 'Concluding Observations of the Committee on Economic, Social and Cultural Rights, Colombia' UN Doc E/C.12/ $\mathrm{COL} / \mathrm{CO} / 5,7$ June 2010, para 25), the Sami people (see UNCESCR, E/C.12/NOR/ $\mathrm{CO} / 5$ (n 78) para 17), indigenous peoples (see UNCESCR, E/C.12/CAN/CO/6 (n 56) paras 19,49), persons with immigrant background (see UNCESCR, E/C.12/GRC/CO/2 (n 63) para 9), gypsies (see UNCESCR, 'Concluding Observations of the Committee 
is required at all stages. ${ }^{80}$

Fourthly, all appropriate means must be used including legislative measures. $^{81}$ However, legislative measures alone are not sufficient; effective remedies, including judicial remedies, are also required.$^{82}$ It is important to note that legislative measures should establish access to effective remedies, ${ }^{83}$ and combat discrimination. ${ }^{84}$ In engaging in all these actions, resources should be increased. ${ }^{85}$ Not only that, States must also dedicate efforts to international cooperation. ${ }^{86}$ International cooperation must be based on the principle of the equal sovereignty of States $^{87}$ and be oriented towards the establishment of a social and international order in which the rights of the Covenant can be fully realized ${ }^{88}$ In this regard, the Maastricht Guidelines consider a violation to be the failure of a State not to take into account its international legal obligations in the field of economic, social and cultural rights when entering into bilateral or multilateral agreements with other States, international organizations or multinational corporations. ${ }^{89}$

on Economic, Social and Cultural Rights, Spain', UN Doc E/C.12/ESP/CO/5, 6 June 2012, para 11), the Maori (see UNCESCR, 'Concluding Observations of the Committee on Economic, Social and Cultural Rights, New Zealand', UN Doc E/C.12/NZL/CO/3, 31 May 2012, para 12), the Dalits (see UNCESCR, 'Concluding Observations on the Third Periodic Report of Nepal' UN Doc E/C.12/NPL/CO/3, 12 December 2014, para 11), Crimean Tatars (see UNCESCR, 'Concluding Observations on the Sixth Periodic Report of Ukraine' UN Doc E/C.12/UKR/CO/6, 13 June 2014, para 9), Al-Akhdam people (see UNCESCR, 'Concluding Observations of the Committee on Economic, Social and Cultural Rights, Yemen' UN Doc E/C.12/YEM/CO/2, 22 June 2011, para 8) among others; in some cases, the Committee focuses on cases that involve various interlinked grounds of prohibited discrimination (see UNCESCR, 'Concluding Observations of the Committee on Economic, Social and Cultural Rights, Estonia' UN Doc E/C.12/1/Add.85, 19 December 2002, para 49).

$80 \quad$ Limburg Principles (n 47) para 11.

81 ibid para 17; UNCESCR, Comment 3 (n 68) para 3; UNCESCR, 'Concluding Observations of the Committee on Economic, Social and Cultural Rights, Iran', UN Doc E/C.12/1993/7, 9 June 1993, para 8.

82 Limburg Principles (n 47) para 19; UNCESCR, Comment 3 (n 68) para 5; UNCESCR, Comment 14 (n 55) para 60; UNCESCR, E/C.12/CAN/CO/4-5 (n 69) para 36.

83 UNCESCR, E/C.12/CAN/CO/6 (n 56) para 6.

84 UNCESCR, 'Concluding Observations on the Initial Report of Burkina Faso', UN Doc E/C.12/BFA/CO/1, 12 July 2016, para 11.

${ }_{85}$ Limburg Principles (n 47) para 23; UNCESCR, E/C.12/COL/CO/5 (n 79) para 26.

86 Limburg Principles (n 47) para 26; UNCESCR, E/C.12/FRA/CO/4 (n 78) para 7.

87 Limburg Principles (n 47) para 33; Maastricht Principles (n 50) para 10.

88 Limburg Principles (n 47) para 30.

89 Maastricht Guidelines (n 48) para 15(j); UNCESCR, Comment 14 (n 55) para 50; Maastricht Principles (n 50) paras 17, 29, 32-35; UNCESCR, 'Concluding 
Concerning their extraterritorial obligations in the area of economic, social and cultural rights, States are expected to act with due diligence. ${ }^{90}$ With respect to acts by international organizations, States hold responsibility to protect and must influence, encourage and generalize the trend for these organizations to revise their policies and programmes so that they consider economic, social and cultural rights. ${ }^{91}$ This consideration must take place in an equitable and effective way, ${ }^{92}$ constantly monitoring progress ${ }^{93}$ based on targets, goals, benchmarks and indicators. ${ }^{94}$

\subsubsection{Non-compliance}

What does lack of compliance amount to? In observing the Covenant's obligations, State Parties are afforded a margin of discretion. ${ }^{95}$ Yet, a failure by a State Party to comply with an obligation contained in the Covenant is considered a violation of it under international law. ${ }^{96}$

Violations of the Covenant may occur either by action or omission. ${ }^{97}$ A State Party will be considered to have violated the Covenant if it fails, inter alia,

Observations of the Committee on Economic, Social and Cultural Rights, Ecuador', UN Doc E/C.12/1/Add.100, 7 June 2004, para 55; UNCESCR, E/C.12/COL/CO/5 (n 79) para 10.

90 Maastricht Guidelines (n 48) para 18; various principles within the Guiding Principles on Business and Human Rights address the notion of due diligence, see OHCHR, Business (n 51) principles 4, 15, 17; OHCHR, Poverty (n 78) para 56; UNCESCR, E/C.12/CAN/CO/6 (n 56) para 16; UNCESCR, E/C.12/FRA/CO/4 (n 78) para 7.

91 Maastricht Guidelines (n 48) para 19; Maastricht Principles (n 50) para 15; UNCESCR, E/C.12/FRA/CO/4 (n 78) para 11; UNCESCR, 'Concluding Observations of the Committee on Economic, Social and Cultural Rights, Ireland', UN Doc E/C.12/1/ Add.77, 5 June 2002, para 37.

92 Limburg Principles (n 47) paras 23, 27; UNHRCL, A/HRC/7/11 (n 67) paras 43, 50; UNCESCR, 'Concluding Observations of the Committee on Economic, Social and Cultural Rights, New Zealand', UN Doc E/C.12/1/Add.88, 26 June 2003, para 34; UNCESCR, E/C.12/1/Add.94 (n 78) para 59.

93 UNCESCR, 'General Comment 1: Reporting by States Parties', UN Doc E/1989/22, 27 July 1981, para 4; UNCESCR, Comment 3 (n 68) para 11.

94 Limburg Principles (n 47) paras 79, 89; UNCESCR, Comment 1 (n 93) para 6; UNHRCL, A/HRC/7/11 (n 67) para 48; OHCHR, Vienna (n 46) para 98; UNCHR, E/ CN.4/2006/48 (n 60) paras 22, 26, 27, 34; UNCESCR, 'Concluding Observations of the Committee on Economic, Social and Cultural Rights, Bolivia', UN Doc E/C.12/ BOL/CO/2, 8 August 2008, paras 13, 26; UNCESCR, 'Concluding Observations on the Combined Second and Third Periodic Reports of Albania', UN Doc E/C.12/ALB/ CO/2-3, 18 December 2013, para 12.

95 Limburg Principles (n 47) para 71; Maastricht Guidelines (n 48) para 8.

96 Limburg Principles (n 47) para 70; Maastricht Guidelines (n 48) paras 5, 6, 11;

UNCESCR, E/C.12/CAN/CO/6 (n 56) para 5.

${ }_{97}$ Maastricht Guidelines (n 48) paras 14, 15. 
to take a step which it is required to take by virtue of the Covenant; it fails to promptly remove obstacles which it is under a duty to remove to permit the immediate fulfilment of a right; it fails to implement without delay a right which it is required by the Covenant to provide immediately; it wilfully fails to meet a generally accepted international minimum standard of achievement, which is within its powers to meet; it applies a limitation to a right recognized in the Covenant other than in accordance with the Covenant; it deliberately retards or halts the progressive realization of a right, unless it is acting within a limitation permitted by the Covenant or it does so due to a lack of available resources or force majeure, or it fails to submit reports as required under the Covenant. ${ }^{98}$

\subsubsection{Accountability}

What are the consequences of lack of compliance? The State must establish mechanisms to correct such violations including monitoring, investigation, prosecution and remedies for victims. ${ }^{99}$

Moreover, any person or group who is a victim of a violation of an economic, social or cultural right should have access to effective judicial or other appropriate remedies at both national and international levels. ${ }^{100}$ All victims of violations of economic, social and cultural rights are entitled to adequate reparation, which may take the form of restitution, compensation, rehabilitation and satisfaction or guarantees of non-repetition. ${ }^{101}$

\subsubsection{Specificities of the right to health}

The right to health is linked to other human rights including the right to food, housing, work, education, human dignity, life, non-discrimination, equality, the prohibition against torture, privacy, access to information and the freedoms of association, assembly and movement. ${ }^{102}$

The right to health goes beyond the right to healthcare. The right to health embraces a wide range of socioeconomic factors that promote conditions in which people can lead a healthy life and extends to the underlying determinants of health, such as food and nutrition, housing, access to safe and potable

\footnotetext{
98 Limburg Principles (n 47) para 72; ibid paras 14, 15.

99 Maastricht Guidelines ( $\mathrm{48}$ ) para 16; Maastricht Principles (n 50) para 37; UNCESCR, E/C.12/LBN/CO/2 (n 60) paras 18, 19(d).

100 Maastricht Guidelines (n 48) para 22; UNCESCR, Comment 14 (n 55) para 59.

101 Maastricht Guidelines (n 48) para 23; UNCESCR, Comment 20 (n 69) para 40; Maastricht Principles (n 50) para 38; UNCESCR, E/C.12/GTM/CO/3 (n 78) para. 7.

102 UNCESCR, Comment 14 (n 55) para 3.
} 
water and adequate sanitation, safe and healthy working conditions and a healthy environment. ${ }^{103}$

The right to health is comprised of both freedoms and entitlements. The freedoms include the right to control one's health and body, including sexual and reproductive freedom, and the right to be free from interference, such as the right to be free from torture, non-consensual medical treatment and experimentation. By contrast, the entitlements include the right to a system of health protection, which provides equality of opportunity for people to enjoy the highest attainable level of health. ${ }^{104}$

Primary healthcare and other elements of the Alma-Ata Declaration ${ }^{105}$ are considered important in the context of the progressive realization of the right to health.

The right to health's normative content is comprised of several interrelated and essential elements: ${ }^{106}$

- Availability. There should be a sufficient quantity of facilities, goods and services.

- Accessibility. Access should be for everyone within the jurisdiction of the State Party. This element is comprised of: non-discrimination, physical accessibility (for all sections of the population, especially the vulnerable and including rural areas), economic accessibility, which means that health facilities, goods and services must be affordable for all. ${ }^{107}$ Payment for healthcare services, as well as services related to the underlying

103 ibid paras 4, 11; UNHRCL, A/HRC/7/11 (n 67) para 45; UNCHR, E/ CN.4/2006/48 (n 60) paras 4, 5, 9.

104 UNCESCR, Comment 14 (n 55) para 8; UNHRCL, A/HRC/7/11 (n 67) para 15; UNHRCL, A/HRC/17/25 (n 59) paras 4, 5, 10.

105 The Alma-Ata Declaration was the result of a conference held by representatives of the WHO in 1978. The Declaration is considered one of the most important international documents in the field of health. The Declaration considers the right to health a fundamental human right in no way disconnected from the combatting of national and international health inequities. To this purpose the Declaration considers that in order to attain the goal of health for all, action on health should be based on primary healthcare, international cooperation in line with the New International Economic Order, inter-sectorial collaboration, popular participation and communitarian action in the field of health. WHO, 'Primary Health Care: Report of the International Conference on Primary Health Care, Alma-Ata, USSR' (6-12 September 1978); UNHRCL, A/ HRC/7/11 (n 67) paras 21, 22, 24, 47; UNCESCR, 'Concluding Observations on the Combined Second and Third Periodic Reports of Tajikistan', UN Doc E/2007/22, 23 November 2006, para 507; UNCESCR, 'Concluding Observations on the Combined Second to Fourth Periodic Reports of the Former Yugoslav Republic of Macedonia', UN Doc E/C.12/MKD/CO/2-4, 15 July 2016, para 16.

106 UNCESCR, Comment 14 (n 55) para 12.

107 UNCESCR, E/C.12/IND/CO/5 (n 74) para 73. 
determinants of health, must be based on the principle of equity, ensuring that these services, whether provided privately or publicly, are affordable for all, including socially disadvantaged groups. Equity demands that poorer households should not be disproportionately burdened with health expenses as compared to richer households. In this respect, the Guiding Principles on Extreme Poverty and Human Rights establish that States should ensure the affordability of facilities, goods and services relevant to those living in poverty. No one should be denied access to essential services because of an inability to pay. In some cases, States must provide free access; for example, primary education must be compulsory and free of direct and indirect costs. ${ }^{108}$ States should ensure that facilities, goods and services used by persons living in poverty are of the highest attainable quality, including by monitoring the quality of public and private service providers. Providers must be well qualified and aware of the particular needs of persons living in poverty. ${ }^{109}$ States should ensure that persons living in poverty have access to safe and affordable medicines and that inability to pay does not prevent access to essential healthcare and medicine. ${ }^{110}$ Finally, information accessibility includes the right to seek, receive and impart information and ideas concerning health issues.

- Acceptability. All health facilities, goods and services must be respectful of medical ethics and culturally appropriate.

- Quality. This requires skilled medical personnel, scientifically approved and unexpired drugs and hospital equipment, safe and potable water and adequate sanitation.

Article 12(2)(d) of the Covenant is interpreted as including the provision of equal and timely access to basic preventive, curative, rehabilitative health services and health education, regular screening programmes, appropriate treatment of prevalent diseases, the provision of essential drugs, appropriate mental health treatment and care, participation of the population and participation in political decisions relating to the right to health taken at both the community and national levels. ${ }^{11}$

Within the right to health, a number of obligations are considered essential. ${ }^{112}$ Based on the Programme of Action of the International Conference on

108 OHCHR, Poverty (n 78) para 58.

109 ibid para 60.

110 OHCHR, Poverty (n 78) para 82(c).

111 UNCESCR, Comment 14 (n 55) para 17.

112 ibid para 43; UNHRCL, A/HRC/7/11 (n 67) paras 51-53. 
Population and Development ${ }^{113}$ and the Alma-Ata Declaration, the following are considered to be core obligations:

- to ensure the right of access to health on a non-discriminatory basis, especially for vulnerable or marginalized groups;

- to ensure access to the minimum essential food which is nutritionally adequate and safe, to ensure freedom from hunger to everyone;

- to ensure access to basic shelter, housing and sanitation, and an adequate supply of safe and potable water;

- to provide essential drugs, as defined from time to time under the World Health Organization Action Programme on Essential Drugs;

- to ensure equitable distribution of all health facilities, goods and services;

- to adopt and implement a national public health strategy and plan of action, on the basis of epidemiological evidence, addressing the health concerns of the whole population; the strategy and plan of action shall be devised, and periodically reviewed, on the basis of a participatory and transparent process; they shall include methods, such as right to health indicators and benchmarks, by which progress can be closely monitored; the process by which the strategy and plan of action are devised, as well as their content, shall give particular attention to all vulnerable or marginalized groups.

The Committee considers that the following are obligations comparable in priority to core obligations: ${ }^{114}$

- to ensure reproductive, maternal (prenatal as well as post-natal) and child healthcare;

- to provide immunization against the major infectious diseases occurring in the community;

- to take measures to prevent, treat and control epidemic and endemic diseases;

- to provide education and access to information concerning the main health problems in the community, including methods of preventing and controlling them;

- to provide appropriate training for health personnel, including education on health and human rights.

113 UNFPA, 'Report of the International Conference on Population and Development', UN Doc A/CONF.171/13/Rev.1, 5-13 September 1994.

114 UNCESCR, Comment 14 (n 55) para 44. 
As stated before, violations of the Covenant can be the result of either action or omission by the State. ${ }^{115}$ The following are considered to apply in particular in the context of the right to health:

- Violations of the obligation to respect are those that contravene the standards set out in Article 12 and are likely to result in bodily harm, unnecessary morbidity and preventable mortality. ${ }^{116}$

- Violations of the obligation to protect follow from the failure of a State to take all necessary measures to safeguard persons within their jurisdiction from infringements of the right to health by third parties. ${ }^{117}$

- Violations of the obligation to fulfil. These occur through the failure of States Parties to take all necessary steps to ensure the realization of the right to health. Examples include: insufficient expenditures or misallocation of public resources, failure of monitoring, failure to reduce the inequitable distribution of health facilities, failure to adopt a gender-sensitive approach and the failure to reduce infant and maternal mortality rates. ${ }^{118}$

\subsection{Analysis}

The Human Rights World Conference held in Vienna in 1993 represented a decisive moment in the evolution of human rights. Although economic, social and cultural rights existed as human rights before, this moment marked the acceptation of the family of rights preponderant in the Western tradition. The Vienna Declaration had the merit of placing economic, social and cultural rights on an equal footing with civil and political rights. In a statement that would become rephrased numerous times, the Conference held:

All human rights are universal, indivisible and interdependent and interrelated. The international community must treat human rights globally in a fair and equal manner, on the same footing, and with the same emphasis. While the significance of national and regional particularities and various historical, cultural and religious backgrounds must be borne in mind, it is the duty of States, regardless of their political, economic and cultural systems, to promote and protect all human rights and fundamental freedoms. ${ }^{119}$

Since its inception in 1952, the International Commission of Jurists has focused on the rule of law. During the first two decades of its existence, it

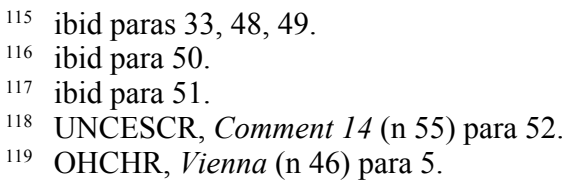


was an unreserved player in the Cold War context. ${ }^{120}$ In the field of economic, social and cultural rights, its work dates back to the early 1980 s. $^{121}$ In its conceptualization, the Commission placed the judiciary at the centre through a focus on access to remedies, minimums and non-discrimination. ${ }^{122}$ This approach pervaded the interpretation through which official bodies understood this set of rights. The so-called tripartite typology of duties, obligation to respect, obligation to protect and obligation to fulfil, operationalized its views. According to Toebes, the tripartite typology of duties is a functional theoretical concept widely recognized in international human rights law. Its purpose is to 'clarify the obligations inherent to all human rights'. ${ }^{123}$ For Toebes, the origins of the doctrine are to be found in Henry Shue's theory of Basic Rights that was published in $1980 .{ }^{124}$ In analysing the history of the typology, Toebes observes that Asbjørn Eide successfully applied this framework to the right to food in his role of Special Rapporteur of this human right, back in the 1980s. ${ }^{125}$ Only with some alterations that Eide would have introduced in Shue's original notion of the obligation to protect, the tripartite typology of duties would date back to that time. As shown above in Section 4.2.7, the obligations to respect, protect and fulfil are structured by the Committee in its General Comment 14; more specifically, in what the Committee calls 'the normative framework of the right to health', also known as 'the AAAQ' (availability, accessibility, acceptability and quality). Despite some innovations, General Comment 14 is not conceptually far removed from the Committee's interpretation of the obligation to take steps under Article 2(1) of the Covenant (General Comment 3).

Throughout the decade 1986 to 1997, the Committee effectively absorbed the International Commission of Jurists' interpretation put forward in the Limburg Principles and the Maastricht Guidelines. This was why the organi-

120 ICJ, International Congress of Jurists. West Berlin 1952: Complete Report, Discourses, Protocols (ICJ 1952) <https://www.icj.org/international-congress-of -jurists-west-berlin-1952-complete-report-discourses-and-protocols $>$ accessed 3 February 2021; ICJ, 'For the Rule of Law' Bulletin no 1 (ICJ 1954); ICJ, Injustice The Regime: Documentary Evidence of the Systematic Violation of Legal Rights in the Soviet Zone of Germany: 1954-1958 (Rudolf Otto 1958).

121 ICJ, 'History' <https://www.icj.org/history/part-two-1970-1990/> accessed 3 February 2021; Philip Alston, 'Development and the Rule of Law' (ICJ, 1981) <https:// www.icj.org/development-and-the-rule-of-law-prevention-versus-cure-as-a-human -rights-strategy/> accessed 3 February 2021; Asbjørn Eide, 'Realisation of Social and Economic Rights - The Minimum Threshold Approach' (1989) 43 International Commission of Jurists Review 40.

122 Eide (n 121).

123 Toebes (n 1) 311.

124 ibid 307[75].

125 ibid 309. 
zation came to regard the justiciability of economic, social and cultural rights as the development that marked the end of one of the legacies of the Cold War, where only civil and political rights were able to become operational in court. ${ }^{126}$ In the organization's view, the justiciability of these rights entailed the clearest sign that both sets of rights had been put on an equal footing. Justiciability entailed:

[T] hat people who claim to be victims of violations of these rights [economic, social and cultural] are able to file a complaint before an independent and impartial body, to request adequate remedies if a violation has been found to have occurred or to be likely to occur, and to have any remedy enforced. ${ }^{127}$

From the Limburg Principles and other instruments of the organization assessed above, the language of justiciability, lawyers, violations, effective remedies, accountability and the requirement of an independent judiciary occupied a primary role in the definition and organization of the provision of these rights. Economic, social and cultural rights became fundamentally legal notions whose primary place was courts of law. As phrased in a recommendation to Tajikistan, the Committee was concerned:

[A]bout the lack of effective remedies in the event of violations of economic, social and cultural rights, owing to high lawyers' fees and court costs, as well as limited access to free legal aid by rights holders who need it, in particular victims of violations. The Committee recommends that the State party take the necessary measures, including legislative measures, to ensure that free legal aid with regard to economic, social and cultural rights is provided to persons who need it, in particular those belonging to disadvantaged and marginalised groups, and that it is adequate with respect to coverage, eligibility and services provided. ${ }^{128}$

What is the effect of the justiciability on human rights? Justiciability refers to the ability to adjudicate an individual interest enshrined in a right. For this to happen, the interest must be narrowed down so that it can be processed by a court of law. This operation involves shifting both the legal subject and the content of the claim. Regarding the protected legal subject, only an individual or a group are acknowledged. They become the claimants or right holders. In this way, even if the role of the State can still theoretically be linked to the promotion of the general welfare, what matters from the legal point of view is that the entitlements of the right holder can be made actionable in court.

126 ICJ, Courts and the Legal Enforcement of Economic, Social and Cultural Rights: Comparative Experiences of Justiciability (ICJ 2008) 1.

127 ICJ, Courts (n 126) 1.

128 UNCESCR, E/C.12/TJK/CO/2-3 (n 56) para 7. 
A further step is also required. The interest needs to be narrowed down at the level of the claim's content. Given the limited access to economic, social and cultural rights by marginalized individuals and groups, non-discrimination largely assisted that process. As a principle enshrined in both Covenants, non-discrimination had undisputable credentials to influence the structuring of human rights law. This process was completed by the doctrine of minimum core rights. This doctrine, which can be traced back to the Limburg Principles, later to General Comment 3 and further to the Maastricht Guidelines, entails one of the most important pillars of the predominant interpretation of this set of rights. There are two main reasons for the attractiveness of the doctrine. In the first place, it does not close the door to a protection beyond the minimum core. It simply limits itself to the idea that what would be legally impermissible would be to cut off certain basic minimums. These minimums, often interlinked with the principle of non-discrimination, are presented as standards of reasonability. ${ }^{129}$ Thus, as the very notion of reasonability suggests, the first consequence of the doctrine is to allow the identification of a section or segment of the right that would be located beyond ideological contestation. In that way, the doctrine avoids clashing frontally with more maximalist notions of social rights. Secondly, this allegedly non-partisan identification of the content of the claim allows its legal operationalization in the narrowly defined contours of the legal sphere. The doctrine of the minimum core thus opens the way to economic, social and cultural rights as legal rights whenever individual entitlements are at stake.

The attractiveness of the predominant interpretation lies in its legalization or, put more accurately, in its judicialization. It was thanks to this interpretation that social rights drew a great deal of attention, becoming a more common object of legal disputes. In line with so-called rights-based approaches, this interpretation has allowed the establishment of an effective remedy which is said to empower marginalized individuals. ${ }^{130}$

Despite all this progress in the recognition of these human rights, a definition of what social rights are remains stubbornly absent. A recent account appears to corroborate this conclusion. Analysing legally protected socio-economic interests in the case law of the European Court of Human Rights, Ingrid Leijten provides a non-substantive understanding of social rights. In her comprehensive study, this scholar shows how these socio-economically protected interests become especially activated in the light of: (a) minimum core content claims; (b) the rights of persons in a position of disadvantage or marginaliza-

129 Fernando Atria, La Forma del Derecho (Marcial Pons 2016) 287-88.

130 OHCHR, Poverty (n 78) paras 9, 10, 12. 
tion; (c) non-discrimination claims. ${ }^{131}$ Interestingly, none of these categories are distinctive or exclusive of social rights. These elements could well be predicated from civil and political rights. To what extent do these elements assist in the identification of the more specific content of social rights?

\section{UNRESOLVED PROBLEMS}

In the context of the drafting of the Universal Declaration and the ICESCR, the legal nature of the right to health and more generally economic, social and cultural rights, remained moot. Although in principle open to its inclusion, the views of the Western bloc transitioned gradually, in the context of the Cold War, into a mere aspiration to achieve rather than a firm legal commitment. Since the ideas of the Latin American countries, the Soviet bloc, the Middle East and the Asian countries were favourable to these rights, the situation remained in a relative stalemate. Even when these different views grew closer under the presidency of Jimmy Carter, ${ }^{132}$ the balance was tilted with the end of the Cold War. The falling of the Eastern bloc led to even stronger opposition from the US to economic, social and cultural rights. This was particularly manifest under the presidency of Ronald Reagan. ${ }^{133}$ While the 1993 Vienna Conference had the effect of upgrading economic, social and cultural rights to the family of human rights recognized in the West, this also narrowed down the legal substance of these rights. Social rights such as the right to health oscillated between individual rights (Vienna Declaration) and social aspirations (Reagan).

As the Reaganite perspective became associated with the particularities of its country of origin, the challenges for the right to health and social rights were perceived in the judicial plane first and foremost. They were to be operationalized by virtue and in the interest of specific individuals or groups through courts of law. Even though the former Special Rapporteur for the Right to Health, Paul Hunt, insisted that the right to health was primarily a right to

131 Ingrid Leijten, Core Socio-Economic Rights and the European Court of Human Rights (CUP 2018) 220-25.

132 American Association for the International Commission of Jurists, 'Toward an Integrated Human Rights Policy: A Commentary on the Interrelationship of Economic, Social, Cultural, Civil and Political Rights' (American Association for the International Commission of Jurists 1979) <https://www.icj.org/toward-an-integrated-human-righs -policy-a-commentary-on-the-interrelationship-of-economic-social-cultural-civil-and -political-rights/> accessed 3 February 2021.

133 Philip Alston, 'Putting Economic, Social and Cultural Rights Back on the Agenda of the United States' in William F. Schulz (ed), The Future of Human Rights: U.S. Policy for a New Era (University of Pennsylvania Press 2008) 122-23. 
a health system, ${ }^{134}$ in practice, the right to health appears to be an individual entitlement to claim a minimum access to healthcare in court, especially in cases of discrimination. The legal certainty provided by notions such as violations, justiciability and accountability to individual or group victims has come at the price of severing social rights from their communitarian and welfarist rationales. This fundamental tension is at the centre of the predominant interpretation of the right to health.

The Committee's view, expressed in General Comment 14, that the right to health includes the right to a system of health protection which provides equality of opportunity for people to enjoy the highest attainable level of health, ${ }^{135}$ is a further affirmation of this tension. The reason is that so much focus on equality of opportunity unavoidably leaves the door open to various ways in which those healthcare services can be provided, including their private provision. ${ }^{136}$ The question then is: can all forms of private provision - in particular the for-profit provision - serve the goal of equal access to healthcare for all?

Moreover, from the perspective of international cooperation, the agenda of the right to health has shifted. It used to be strongly influenced by Article 28 of the Universal Declaration and, as the next chapter shows, by ideas put forward in the 1970s by poor and developing nations through the New International Economic Order Declaration and the Charter of Economic Rights and Duties of States. In this sense, it is not a coincidence that the Alma-Ata Declaration - possibly the most influential instrument on health as a human right - explicitly envisioned the New International Economic Order as a route to development. ${ }^{137}$ However, one effect of the Limburg Principles has been to develop the idea of violations at the extraterritorial level. The Maastricht Guidelines took a step forward in that direction, ${ }^{138}$ and the Principles on Business and Human Rights and, subsequently, the Maastricht Principles on the Extraterritorial Obligations of States in the Area of Economic, Social and Cultural Rights, completed that work. The extent that social rights have served development dynamics does not seem decisive, however. Despite references to involve human rights in international agreements, the priority of international economic law over human rights law reflects a set of structural deficiencies in this latter framework. Unlike the action of individual States, where human

134 UNHRCL, A/HRC/7/11 (n 67) para 15.

135 See $n 104$.

136 Antenor Hallo de Wolf and Brigit Toebes, 'Assessing Private Sector Involvement in Health Care and Universal Health Coverage in Light of the Right to Health' (2016) 18(2) Health and Human Rights Journal 79, 80.

137 WHO, 'Global Strategy for Health for All by the Year 2000' (WHO 1981) paras III, X.

138 Maastricht Guidelines (n 48) para 15(j). 
rights-based criticism can be very vocal, the tendency regarding economic, social and cultural rights has been to amalgamate the human rights frameworks together with the mainstream political economy.

In this respect, it is worth asking: is it possible that the negative terms in which the predominant interpretation is structured has ended up influencing this social right's final content? The risk, in other words, that the doctrine of the minimum core, instead of leading to basic floors, becomes the final ceiling to attain. Does the notion of the minimum core open the door to the targeted policies privileged by neoliberal politics, which have led to unequal access to social services while fuelling economic inequalities? Does expecting courts to do all the work end up neglecting the institutions in charge of providing the actual care? What if so much focus on non-discrimination reduces the importance of principles and policies such as popular participation, primary healthcare, health promotion or an emphasis on the social determinants of health as established in the Ottawa Charter for Health Promotion and the Alma-Ata Declaration?

In the next chapter I explore a critical notion in relation to the right to health - the principle of solidarity, sometimes also called equity. By contrasting the points of view addressed in this chapter with those of the next chapter, chapters four, five and six will address the questions formulated above. 